\title{
The mRNA sequence polymorphisms of flowering key genes in bolting sensitive or tolerant sugar beet genotypes
}

\author{
Maryam Alimirzaee ${ }^{1}$, Asghar MirZaie-ASL ${ }^{1 *}$, Mohammad ReZa Abdollahi ${ }^{2}$, \\ Hassan Ebrahimi Kolaei ${ }^{3}$, Parviz Fasahat ${ }^{4}$ \\ ${ }^{1}$ Department of Biotechnology, Faculty of Agriculture, Bu-Ali Sina University, Hamedan, I.R. Iran \\ ${ }^{2}$ Department of Agronomy and Plant Breeding, Faculty of Agriculture, Bu-Ali Sina University, Hamedan, I.R. Iran \\ ${ }^{3}$ Sugar Beet Seed Department, Hamedan Agricultural and Natural Resources Research and Education Center, AREEO, Hamedan, Iran \\ ${ }^{4}$ Sugar Beet Seed Institute, Agricultural Research, Education and Extension Organization (AREEO), Karaj, Iran
}

\begin{abstract}
One of the most important characteristics of sugar beet planting in temperate climates is the tolerance against early bolting. Understanding the genetic control of sugar beet flowering can help to develop the bolting-tolerant cultivars. In this study, the transcript sequences of 2 VIN3 copies, frigida, VRN1, EMF2, BVFT1, and BTC1 genes in 4 bolting tolerant and sensitive sugar beet genotypes were evaluated. Leaf samples were taken from plants in 2 growing stages, before and during cold exposure. The amplified fragments of both tolerant and sensitive genotypes were similar in length and the comparison of their transcript sequence showed polymorphism. In overall, 18 mutations comprising 1 mutation in frigida sequence, 14 single nucleotide polymorphisms (SNPs) in 2 copies of $B_{V V I N 3}$ sequence, 2 SNPs in $B_{V F T 1}$ sequence, and 1 insertion/deletion mutation for $B T C 1$ were characterized. The last one caused a frameshift in the encoded protein. Despite the key role of the above mentioned genes, results showed that SNPs identified in this study were not associated with bolting tolerance or sensitivity. There may be differences in the expression levels of these proteins, which necessitates further exploration.
\end{abstract}

Key words: sugar beet, bolting, single nucleotide polymorphism

\section{Introduction}

The transition to flowering is one of the major phase changes that a plant makes during its life cycle. In biennial roots and leaf crops such as sugar beet, the avoidance of flowering is of fundamental importance for high yields and good quality. Sugar beet (Beta vulgaris) is the second important sucrose-storing species in the world. Recent studies showed that sugar beet can be used as a renewable source of energy because of high dry matter production, which makes it a suitable source for methane production (Hoffmann and Kluge-Severin, 2011). Transition to the reproductive stage in sugar beet requires low temperatures (vernalization), followed by longday conditions (Biancardi, 2005). After transitioning to the reproductive stage, the elongation of the main shoot occurs, which results in the reduction of sugar yield.
In contrast, wild beet ( $B$. vulgaris ssp. maritima) is an annual plant, which bolts without vernalization (Lexander, 1980). Genetically, the annual growth habit is under the control of a major dominant gene that has long been referred to as the bolting gene or $B$ (Abegg, 1936). Plants that behave as a biennial carry the recessive alleles $(b b)$, while the annual beets carry homozygous dominant $(B B)$ or heterozygous $(B b)$ alleles. Apart from the major bolting locus $B$, using ethylmethanesulfonate (EMS) mutagenesis, 2 recent studies have identified 2 additional loci ( $B 2$ and $B 4)$, which contribute to the annual bolting in wild beets (Abou-Elwafa et al., 2012; Büttner et al., 2010; Hohmann et al., 2005). At each of these loci, the homozygous recessive genotype bolted only after vernalization.

Pin and coworkers (2012) reported that the $B$ locus encodes a pseudo-response regulator (PRR) gene named

\footnotetext{
${ }^{*}$ Corresponding author: Department of Biotechnology, Faculty of Agriculture, Bu-Ali Sina University, Hamedan, I.R. Iran; email: a.mirzaie@basu.ac.ir
} 
BOLTING TIME CONTROL 1 (BTC1), which has a homology to circadian clock gene PRR7 from Arabidopsis thaliana (Pin et al., 2012). In addition, they indicated that $B T C 1$ is a key regulator in beet life cycle (Pin et al., 2012). Downregulation of BTC1/btc1 expression by RNA interference (RNAi) in both annual and biennial beets caused a continuous vegetative growth (Dally et al., 2014; Pin et al., 2012). In sugar beet, BVFT1 and BVFT2 (FLOWERING LOCUS T homologs) genes act antagonistically in the floral transition. $B V F T 1$ acts as a floral repressor, whereas $B v F T 2$ promotes the flowering and also downregulates $B v F T 1$ expression after vernalization (Pin et al., 2010). It has been shown that $B_{v F T 1}$ repression was stably maintained after plants were moved to warm temperature, suggesting that BVFT1 acts similar to FLOWERING LOCUS C (FLC) (Kim and Sung, 2014). Pin and coworkers (2012) suggested a model whereby $B V B T C 1$ acts upstream of $B v F T 1$ and $B v F T 2$. Annual sugar beet carries a dominant $B T C 1$ allele, which promotes flowering under long days through blocking $F T 1$ and activating $F T 2$. However, in biennials, the recessive $b t c 1$ allele does not repress expression of the floral repressor $F T 1$. Since $B V F T 1$ prevents $B v F T 2$ expression, plants stay in vegetative growth phase before an exposure to vernalization and during vernalization, therefore, $b t c 1$ expression is increased and $B_{V F T 1}$ expression is gradually decreased (Dally et al., 2014).

In $A$. thaliana, $F L C$ acts as a flowering time repressor under its upstream regulator FRIGIDA (FRI) (Johanson et al., 2000). FLC directly represses the expression of $F T$ and SOC1 (Helliwell et al., 2006; Searle et al., 2006). FRI mainly acts to upregulate $F L C$ transcription (Michaels and Amasino, 2001). Before the cold exposure of winter, FLC chromatin is in an active state where through active histone marks, e.g., histone H3 Lys4 (H3K4) and histone H3 Lys36 (H3K36) methylation as well as histone $\mathrm{H} 3$ acetylation are present (He et al., 2003; Kim et al., 2005; Zhao et al., 2005). A prolonged exposure to low temperatures leads to an epigenetic downregulation of FLC (Amasino, 2010). In Arabidopsis, the vernalization-mediated repression of $F L C$ is established by VERNALIZATION INSENSITIVE 3 (VIN3) gene (Sung and Amasino, 2004), VERNALIZATION 2 (VRN2) gene (Le Corre et al., 2002), a homolog of a Suppressor of Zeste 12 gene (a part of a chromatinmodifying complex in Drosophila), and VERNALIZA-
TION 1 (VRN1), a plant-specific DNA-binding protein (Levy et al., 2002). During cold exposure, VIN3 expression is upregulated (Sung and Amasino, 2004). VIN3 contains a plant-specific plant homeodomain (PHD) finger, which is involved in the detection of histone modifications in eukaryotes (Musselman and Kutateladze, 2011). During and after vernalization, repressive histone modifications (i.e., H3K9me2 and H3K27me3) are substantially increased at the $F L C$ chromatin locus (Bastow et al., 2004; Greb et al., 2007; Sung and Amasino, 2004; Sung et al., 2006). VRN1 is required for the methylation of H3K9 and both VIN3 and VRN2 are required for H3K27 methylation at FLC chromatin loci by vernalization (Bastow et al., 2004; Kim and Sung, 2013; Sung and Amasino, 2004). It has been shown that VRN1 expression was increased during cold treatment and it has been maintained at high level even when plants were returned to warm temperatures (Hemming et al., 2008; Trevaskis et al., 2006; Yan et al., 2003). Abou-Elwafa and coworkers (2012) identified and mapped 4 genes (BVFLK, $B v F V E, B v L D$, and $B v L D L 1$ ) in sugar beet that are highly similar to their Arabidopsis counterparts in terms of exon-intron structure and domain organization.

Since the sugar reposition period is not precisely limited and root yield continues to increase as long as the plant does not bolt, increasing the growing season of sugar beet via autumn planting is a basic target to improve sugar beet productivity in temperate regions (Jaggard et al., 2009; Jaggard and Werker, 1999; Jung et al., 2007). The yielding potential of winter beet has been evaluated to be $\sim 20 \%$ higher than that of spring beet (Hoffmann and Kluge-Severin, 2011), but sowing sugar beet in autumn increases the risk of bolting. Identification of flowering-time genes and their sequencing can be useful in the development of bolting-resistant varieties. In this study, mRNA sequences encoded by floweringtime genes including BTC1, BVFT1, frigida, VRN1, $V R N 2$ as well as two copies of VIN3 of bolting tolerant and sensitive genotypes of sugar beet were evaluated.

\section{Materials and methods}

\section{Plant material}

In this study 2 bolting sensitive (OT7112 and MS261) and 2 bolting tolerant (Vico and Posuda) sugar beet genotypes were used. Seeds were provided by the Sugar Beet Seed Institute and they were planted in July at the Re- 
search Agricultural Farm in the suburbs of Hamedan, Iran. Seeds were planted on August $15^{\text {th }}, 2013$ and the first sampling was performed on September 24 before cold imposition and the second sampling was performed on January $4^{\text {th }}, 2014$ during cold imposition. Leaf samples were collected, immediately frozen in liquid $\mathrm{N}$, and stored at $-70^{\circ} \mathrm{C}$ for RNA extraction.

\section{Total RNA extraction and cDNA synthesis}

Total RNA was extracted from the sugar beet leaves using RNX plus solution (CinnaGen Company) according to the manufacturer's instructions. All RNA preparations were treated with RNase-free DNase to remove any genomic DNA contamination. The amounts of RNA were determined by the spectrophotometric method. cDNA fragments were synthesized from $6 \mu \mathrm{g}$ of total RNA using oligo (dT) $)_{12-18}$ primer and M-MuLV reverse transcriptase kit (CinnaGen Company).

\section{Primer design}

We used Arabidopsis thalianagenes that are involved in the flowering-time control as a reference to identify the homologous counterparts in sugar beet GenBank sequences in NCBI (Shojaei et al., 2017). Using Primer Blast software, 9 primer pairs were designed for $B v F T 1$, Bvfrigida, BVVIN3, BVVRN1, BVVRN2, and BTC1 genes from the identified homologs (Table 1 ) and were synthesized by Bioneer company (Seoul, Korea, Table 1).

\section{RT-PCR conditions}

For the mRNA sequence comparison of genes selected from both sensitive and tolerant genotypes, cDNA from samples collected before the cold exposure treatment were used as a template for Bvfrigida and $B v F T 1$ amplification and cDNA from samples collected during the cold exposure were used as a template for BVVIN3,

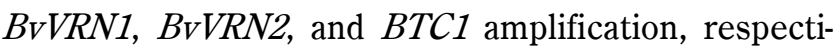
vely. PCR was performed in $25 \mu 1 \mathrm{X}$ PCR buffer containing 20ng cDNA, $0.2 \mathrm{mM}$ dNTP, $1.5 \mathrm{mM} \mathrm{MgCl}_{2}$, 10 pmol of each primer, and $1 \mathrm{U}$ of Pfu DNA polymerase. The cycle parameters in the PCR program were as follows: $94^{\circ} \mathrm{C}$ for $3 \mathrm{~min}, 35$ cycles of $94^{\circ} \mathrm{C}$ for $30 \mathrm{se}-$ conds, $56-61^{\circ} \mathrm{C}$ for 30 seconds, $72^{\circ} \mathrm{C}$ for 2 min followed by a final extension at $72^{\circ} \mathrm{C}$ for $7 \mathrm{~min}$. About $5 \mu \mathrm{l}$ of each $\mathrm{PCR}$ product was run on a $2 \%$ agarose gel in TBE buffer. Amplified fragments were sent for sequencing to the Bioneer Company in South Korea.

\section{Sequencing PCR products}

Sanger sequencing was performed at least twice for each individual primer. The sequencing results were explored in the Reference Sequence (RefSeq) database using BlastX software. Results were also analyzed by the SaqMan program of the Lasergene software. Single nucleotide polymorphisms (SNPs) and point mutations were identified by comparing the sequence chromatograms. mRNA sequences of flowering-time genes deposited in the NCBI database [BioProject: PRJNA268352] were used for the comparison and determination of SNPs. Protein secondary structures were evaluated through (PS)2v2: Protein Structure Prediction Server database (http://ps2.life.nctu.edu.tw).

\section{Results}

A comparison of the amplified mRNA fragments of some flowering genes from all genotypes indicated the differences among their nucleotide sequences. We observed heterozygous alleles in some genotypes, in both $\mathrm{C}$ and $\mathrm{G}$ nucleotides at position 196 in $B V F T 1 \mathrm{mRNA}$ (Table 2). The fragment amplified by VRN2 primer pair had $100 \%$ similarity to EMBRYONIC FLOWER 2 (EMF2) protein in the sugar beet. In this study, the focus was mostly given to the comparison of the coding regions of mRNA sequences in key flowering genes between the bolting sensitive and resistant genotypes. Using Lasergene SaqMan Pro software, the lengths of EMF2 mRNA sequence, about 860 of 1443 bp including the coding sequence, in 4 genotypes and the length of polycomb group protein EMF2 mRNA [GenBank: XM_010695441] were compared. No SNPs were observed among the tested genotypes. Either, there was no polymorphism detected in the $300 \mathrm{bp}$ fragment of 1013 bp of $B V V R N 1$ mRNA sequence containing B3 domain among genotypes. The sequence was similar to $B V V R N 1$ mRNA.

Across 5 genes, namely VIN3-like protein $1 \mathrm{mRNA}$ (BVVIN3-1), VIN3-like protein2 mRNA (BVVIN3-2), $B V F R I, B V F T 1$, and $B T C 1$, a total of 18 SNPs were identified (Table 2); consisting of six SNPs in 722 bp fragment of BVVIN3-1 and 8 SNPs in about $1800 \mathrm{bp}$ sequence compared to BVVIN3-2. The results of the generated protein translation alignment to the DNA sequences showed that the changes in VIN3-like protein1 and VIN3-like protein $2 \mathrm{mRNAs}$ did not cause any changes in 
Table 1. List of primers used in this study

\begin{tabular}{|c|c|c|c|}
\hline Primer & Accession no. & Primer sequences $\left(5^{\prime}-3^{\prime}\right)$ & $\begin{array}{l}\text { Annealing } \\
\text { temperature }\end{array}$ \\
\hline BvFT1 forward & HM448910 & GTGAAGTATTCCTTAGCTTTCTAGC & 56 \\
\hline BvFT1 reverse & & GTTCATTGAAATGGAGAGGTGGA & \\
\hline BvFRI forward & AVZW01032897 & TACTCAGTCCGTTGGTGTGC & 56 \\
\hline BvFRI reverse & & ACGTTTTGCCAGAGTGTCCA & \\
\hline BvVIN3-1 forward & AYZW01007287 & CCAAGATATGTGTGCCGTCCT & 58 \\
\hline BvVIN3-1 reverse & & GCGGGACCTTGGGAAAATCT & \\
\hline BvVIN3-2 forward & AYZW01053336 & CGGTGCTGCAGAAATGCTAC & 56 \\
\hline BvVIN3-2 reverse & & CTGCTCTGAGAGGGATGCTG & \\
\hline BvVIN3-2/2 forward & & AGCCTTCTGATGTCGTTGAT & 58 \\
\hline BVVIN3-2/2 reverse & & TGCTGGGCTCTGAACTCTTT & \\
\hline BvVRN1 forward & JP530325 & CCCAAACAAACAAAGAAGA & \\
\hline BvVRN1 reverse & & TGATATTTCACAAGCAGTCG & 61 \\
\hline BvVRN2 forward & $\begin{array}{l}\text { JP493909 } \\
\text { JP493908 } \\
\text { JP493907 } \\
\text { JP493912 }\end{array}$ & TCCTGTTTTTGGCAACGCTC & \\
\hline BvVRN2 reverse & & CTTGGATTGAGGACCGGCAA & \\
\hline BTC1-1 forward & HQ709093 & AAAATGAAGATGGGCCCGGT & 62 \\
\hline BTC1-1 reverse & & ACACGAGGTCTTTGATCTGCT & \\
\hline BTC1-2 forward & & TGGATCCATGCAGGAACTTGAT & 60 \\
\hline BTC1-2 reverse & & ACACGAGGTCTTTGATCTGCT & \\
\hline
\end{tabular}

the amino acid sequences of proteins, which therefore can be considered as synonym mutations.

A comparison of 1250 bp segment of $B V F R I$ mRNA sequence resulted in the identification of $1 \mathrm{SNP}$ (Table 2). Protein translation demonstrated that the nucleotide substitution of guanine or adenine at position 614 of $B V F R I$ mRNA causes a change to alanine or threonine. Substituting alanine with threonine and vice versa did not result in any changes in the secondary structure of protein.

A comparison of $630 \mathrm{bp}$ sequence of $B v F T 1 \mathrm{mRNA}$ including the coding region allowed identifying 2 transversion mutations (Table 2). If the nucleotide at position 196 is guanine, it would be translated to a glutamate amino acid; while if a nucleotide in this position is replaced by cytosine, the translated amino acid would be glutamine. If the nucleotide at position 433 is replaced by guanine, it would be translated to serine and if the position is replaced by cytosine, it would be translated to threonine. Protein translation and secondary structure prediction was done in 4 forms: guanine ${ }_{196}$ guanine $_{433}$
$\left(\mathrm{G}_{196}-\mathrm{G}_{433}\right)$, guanine ${ }_{196}$ - cytosine $_{433}\left(\mathrm{G}_{196}{ }^{-} \mathrm{C}_{433}\right)$, cytosine ${ }_{196}{ }^{-}$ cytosine $_{433}\left(\mathrm{C}_{196}{ }^{-} \mathrm{C}_{433}\right)$, and cytosine ${ }_{196}{ }^{-}$guanine ${ }_{433}\left(\mathrm{C}_{196}{ }^{-}\right.$ $\mathrm{G}_{433}$ ). Protein structure prediction showed a change in $\mathrm{C}_{196}-\mathrm{C}_{433}$ when compared with other abovementioned forms (Fig. 1). To determine the effect of this mutation on bolting tolerance, $B_{V} F T 1$ mRNA comparison was performed in further bolting-resistant genotypes including Monotana and Giada. SNPs observed in these genotypes were similar to the bolting-sensitive genotypes.

A comparison of $2225 \mathrm{bp}$ sequence of $B T C 1 \mathrm{mRNA}$ identified 1 deletion with a frameshift change at the end of the related protein (Table 2). This deletion was identified in 7112 and 261 bolting-sensitive genotypes and in the bolting-resistant Monotana genotype.

\section{Discussion}

At the time of conducting this study, the sugar beet genome was released and the complete genomic sequence of double haploid sugar beet line KWS2320, as a reference genotype, was reported (Dohm et al., 2014). 
Table 2. Identification of SNPs in selected flowering-time genes in both bolting sensitive and tolerant genotypes

\begin{tabular}{|c|c|c|c|c|c|c|c|c|c|c|}
\hline \multirow{2}{*}{ Gene } & \multirow{2}{*}{ Reference gene* } & \multirow{2}{*}{$\begin{array}{l}\text { mRNA length } \\
\text { (bp) }\end{array}$} & \multirow{2}{*}{$\begin{array}{l}\text { Nucleotide } \\
\text { number }\end{array}$} & \multirow{2}{*}{$\begin{array}{l}\text { Modified } \\
\text { amino acid }\end{array}$} & \multicolumn{6}{|c|}{ Nucleotide type for position mutation in each genotype } \\
\hline & & & & & 7112 & 261 & Vico & Pusoda & Monotana & Giada \\
\hline BvVIN3-1 & XM_010689861 & 2949 & 2107 & no & $\mathrm{Y}(\mathrm{C}$ or $\mathrm{T})$ & $\mathrm{T}$ & $\mathrm{W}(\mathrm{A}$ or $\mathrm{T})$ & $\mathrm{R}(\mathrm{A}$ or $\mathrm{G})$ & - & - \\
\hline BvVIN3-1 & XM_010689861 & 2949 & 2344 & no & $\mathrm{Y}(\mathrm{C}$ or $\mathrm{T})$ & $\mathrm{C}$ & $\mathrm{Y}(\mathrm{C}$ or $\mathrm{T})$ & $\mathrm{Y}(\mathrm{C}$ or $\mathrm{T})$ & - & - \\
\hline BvVIN3-1 & XM_010689861 & 2949 & 2362 & no & $\mathrm{R}(\mathrm{A}$ or $\mathrm{G})$ & A & $\mathrm{R}(\mathrm{A}$ or $\mathrm{G})$ & $R(A$ or $G)$ & - & - \\
\hline BvVIN3-1 & XM_010689861 & 2949 & 2395 & no & $\mathrm{C}$ & $\mathrm{C}$ & $\mathrm{Y}(\mathrm{C}$ or $\mathrm{T})$ & $\mathrm{Y}(\mathrm{C}$ or $\mathrm{T})$ & - & - \\
\hline BvVIN3-1 & XM_010689861 & 2949 & 2518 & no & $\mathrm{C}$ & $\mathrm{C}$ & $\mathrm{Y}(\mathrm{C}$ or $\mathrm{T})$ & $\mathrm{T}$ & - & - \\
\hline BvVIN3-1 & XM_010689861 & 2949 & 2572 & no & $\mathrm{G}$ & $\mathrm{G}$ & $\mathrm{A}$ & $\mathrm{A}$ & - & - \\
\hline BvVIN3-2 & XM_010690174 & 2704 & 608 & no & $\mathrm{T}$ & $\mathrm{T}$ & $\mathrm{W}(\mathrm{A}$ or $\mathrm{T})$ & $\mathrm{T}$ & - & - \\
\hline BvVIN3-2 & XM_010690174 & 2704 & 847 & no & $R(A$ or $G)$ & $\mathrm{G}$ & $\mathrm{G}$ & $\mathrm{R}(\mathrm{A}$ or $\mathrm{G})$ & - & - \\
\hline BvVIN3-2 & XM_010690174 & 2704 & 1264 & no & A & $R(A$ or $G)$ & $\mathrm{G}$ & $R(A$ or $G)$ & - & - \\
\hline BvVIN3-2 & XM_010690174 & 2704 & 1548 & no & $\mathrm{T}$ & $\mathrm{T}$ & $\mathrm{Y}(\mathrm{C}$ or $\mathrm{T})$ & $\mathrm{T}$ & - & - \\
\hline BvVIN3-2 & XM_010690174 & 2704 & 1798 & no & $\mathrm{Y}(\mathrm{C}$ or $\mathrm{T})$ & $\mathrm{T}$ & $\mathrm{T}$ & $\mathrm{Y}(\mathrm{C}$ or $\mathrm{T})$ & - & - \\
\hline BvVIN3-2 & XM_010690174 & 2704 & 1864 & no & $\mathrm{Y}(\mathrm{C}$ or $\mathrm{T})$ & $\mathrm{C}$ & $\mathrm{C}$ & $\mathrm{Y}(\mathrm{C}$ or $\mathrm{T})$ & - & - \\
\hline BvVIN3-2 & XM_010690174 & 2704 & 2042 & no & $\mathrm{C}$ & $\mathrm{M}(\mathrm{A}$ or $\mathrm{C})$ & $\mathrm{C}$ & $\mathrm{C}$ & - & - \\
\hline BvVIN3-2 & XM_010690174 & 2704 & 2164 & no & $\mathrm{T}$ & $\mathrm{A}$ & $\mathrm{A}$ & $\mathrm{A}$ & - & - \\
\hline BVFT1 & XM_010692083 & 902 & 196 & yes & $\mathrm{G}$ & $\mathrm{S}(\mathrm{C}$ or $\mathrm{G})$ & $\mathrm{S}(\mathrm{C}$ or $\mathrm{G})$ & $\mathrm{S}(\mathrm{C}$ or $\mathrm{G})$ & $\mathrm{G}$ & $\mathrm{S}(\mathrm{C}$ or $\mathrm{G})$ \\
\hline BVFT1 & XM_010692083 & 902 & 433 & yes & G & G & $\mathrm{S}(\mathrm{C}$ or $\mathrm{G})$ & $\mathrm{S}(\mathrm{C}$ or $\mathrm{G})$ & G & G \\
\hline BvFRI & XM_010680700 & 2303 & 614 & yes & $\mathrm{R}(\mathrm{G}$ or $\mathrm{A})$ & $\mathrm{G}$ & $\mathrm{R}$ & $\mathrm{G}$ & - & - \\
\hline BTC1 & HQ709093 & 2367 & 2222 & yes & - & - & $\mathrm{T}$ & - & - & - \\
\hline
\end{tabular}

*sequences have been used as a reference for the comparison and determination of SNPs 
We deposited Bvfrigida mRNA sequence with the accession number KJ755196.1 and BVVIN3 mRNA sequence with the accession number KJ755197.1 in the GenBank database (unpublished data) before the sugar beet genome release. The sugar beet genome sequence provided a better comparison of flowering key gene sequences. After sugar beet genome release, we noted that the fragment amplified by VRN2 primer pair had $100 \%$ similarity to EMBRYONIC FLOWER 2 protein in the sugar beet. This protein contains VEFS-box domain, which also exists in VRN2, FIS2, and $\mathrm{Su}(\mathrm{z}) 12$ proteins (Birve et al., 2001; Gendall et al., 2001; Köhler and Grossniklaus, 2002; Luo et al., 1999; Yoshida et al., 2001). EMF2 mRNA is expressed throughout the life cycle of Arabidopsis without any significant changes during its growth (Köhler and Grossniklaus, 2002).

In the sugar beet genome database at NCBI, 3 BVVIN3 sequences have been deposited. VIN3-like 1 is located on chromosome 8 while 2 VIN3-like 2 genes are located on chromosomes 1 and 8. These 2 VIN3-like 2 mRNAs have only $17 \%$ coverage with $68 \%$ identity in the nucleotide blast result. VIN3 is a PHD motif containing protein. It has been shown that VIN3 mRNA levels directly correlate with the vernalization response (Sung and Amasino, 2004). VIN3 is necessary for both histone H3 Lys 9 and histone H Lys 27 methylation at the FLC chromatin locus. Kim and Sung (2010) introduced a point mutation in the PHD finger motif of VIN3-LIKE 2 (VIL2) in Arabidopsis. This mutation resulted in the substitution of 1 cysteine residue, which is important for finger structure formation with alanine preventing VIL2 from binding to modified histone peptides (Kim and Sung, 2010). PHD is vital for finger binding specificity (Kim and Sung, 2010; Li et al., 2007). In the present study, 2 copies of VIN3 mRNA in sugar beet were investigated and 12 SNPs (Table 2) were identified, but none of them resulted in any changes in the specific domain or the conserved regions of protein sequences.

The dominant FRIgene in Arabidopsis upregulates the $F L C$ expression and as a consequence delays the flowering. Mutations occurring naturally in FRI locus cause early flowering without vernalization in most Arabidopsis accessions (Johanson et al., 2000; Strange et al., 2011). Although the mutation in the FRI gene in Arabidopsis has a major contribution to flowering-time variations, the comparison of $1250 \mathrm{bp}$ of $B_{V} F R I$ mRNA sequence among 4 sugar beet genotypes identified a single point mutation $\left[B V F R I\left(\mathrm{~A}_{614}\right)\right.$ or $\left.\left(\mathrm{G}_{614}\right)\right]$. However, this SNP was not related to bolting as 2 nucleotide types ( $\mathrm{G}$ or $\mathrm{A}$ ) for this position mutation were observed in both sensitive and tolerant genotypes (Table 2). In all genotypes, GCG or ACG code is translated to alanine or threonine amino acid, respectively. Substitution in the aforementioned amino acids did not create any changes in the protein secondary structure. Although FRI influences bolting in Arabidopsis (Le Corre et al., 2002), it appears that mutants identified in this gene, especially in our study, have no association with bolting tolerance in sugar beet.

$B v F T 1$ is known to be a flowering suppressor and its expression is downregulated by the vernalization (Pin et al., 2010). Frerichmann and coworkers (2013) identified a single point mutation in exon 4 of $B V F T 1$ by EcoTILLING method in fodder beet, leaf beet, garden beet, and sugar beet (Frerichmann et al., 2013). However, they did not detect any haplotype variation effect of $B V F T 1$ on the bolting rate (Frerichmann et al., 2013). In our study, 2 SNPs were identified in nucleotide positions 196 and 433 when compared with $B v F T 1$ mRNA deposited in the GenBank database. The mutation at the nucleotide position 196 caused substitution of glutamine with glutamate amino acid and the mutation in nucleotide position 433 caused substitution of threonine with serine. The protein structure prediction showed a change in alpha helix in positions $\mathrm{C}_{196}-\mathrm{C}_{433}$ (Fig. 1). It was reported that $B_{V F T 1}$ downregulation after vernalization remained constant even after returning the plant to warm temperatures, indicating that $B V F T 1$ acted similar to $F L C$ (Pin et al., 2010). Considering the key role of $B_{V F T 1}$ in sugar beet, which is similar to FLC in Arabidopsis, it is plausible that the response to bolting among sugar beet genotypes originates in different FT proteins. However, due to the occurrence and position of mutations in both tolerant and sensitive genotypes it seems that mutation positioning has no relation to the bolting resistance.

One-nucleotide ins/del mutation was identified in BTC1 mRNA sequence. In Vico genotype at there was $\mathrm{T}$ at position 2222 present, but a lack of nucleotide was observed in other genotypes. BTC1 encodes a protein that contains a response regulator receiver (REC) and a CONSTANS, CO-like, and TOC1 (CCT) domain (Dally et al., 2014; Pin et al., 2012). In annuals, BTC1 represses $B_{V} F T 1$ and activates $B v F T 2$ to promote the bolting and flowering (Dally et al., 2014; Pin et al., 2012). 

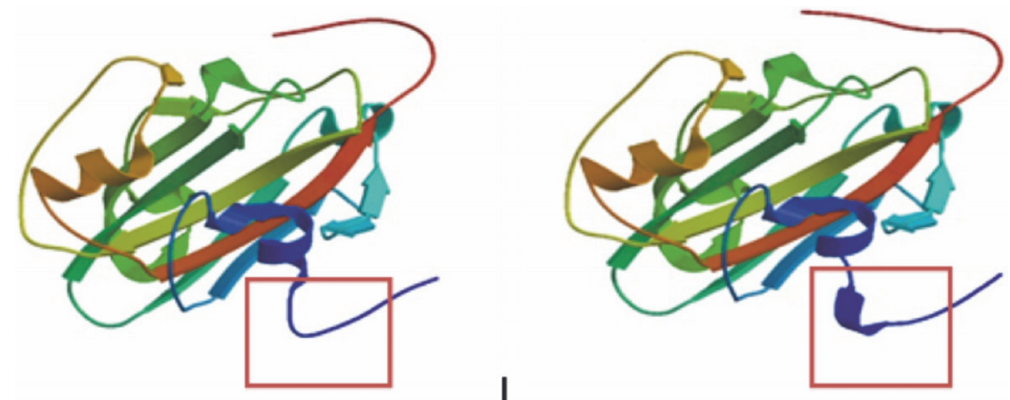

Fig. 1. Protein structure prediction of $B v F T 1$ SNPs: $A)$ in $\mathrm{C}_{196}-\mathrm{C}_{433}$ form, $\left.\mathrm{B}\right)$ in $\left(\mathrm{G}_{196}-\mathrm{G}_{433}\right),\left(\mathrm{G}_{196}{ }^{-} \mathrm{C}_{433}\right)$, and $\left(\mathrm{C}_{196}-\mathrm{G}_{433}\right)$; the red box indicates the difference

Beets carrying the dominant $B T C 1$ allele display an annual growth habit, while the biennial beets have recessive $b t c 1$ allele. Pin and coworkers (2012) surveyed $B T C 1$ allele in haploid annual and biennial beets. BTC1 allele in annual and biennial beets differed by 11 nonsynonymous SNPs and $\sim 28 \mathrm{kbp}$ insertion in $5^{\prime} \mathrm{UTR}$ region, which was present only in biennial beets (Pin et al., 2012). In 3 biennial haploid beets, 2 transition mutations were identified in exons no. 7 and 8 , respectively (Pin et al., 2012). Frerichmann and coworkers (2013) identified 2 point mutations in noncoding regions of BTC1 by EcoTILLING (Frerichmann et al., 2013). Although $B T C 1$ is known as a bolting promoter without proceeding to the vernalization requirement (Pin et al., 2012), in our study, 1 deletion that caused a frameshift change at the end of the protein was identified in boltingsensitive genotypes 7112 and 261 and in the boltingresistant Monotana genotype. For $B V F T 1$ and $B T C 1$ no significant difference was observed among their fragments in bolting sensitive or resistant genotypes.

Despite the key role of the studied genes, results have shown that the identified SNPs were not associated with the bolting tolerance or sensitivity. There may be differences in the expression levels of these proteins, but it requires further exploration.

\section{Acknowledgments}

This research was partly supported by the Iran National Science Foundation (Project 90005176). The Sugar Beet Seed Institute is highly appreciated for providing seeds.

\section{References}

Abegg F.A. (1936) A genetic factor for the annual habit in beets and linkage relationship (US Government Printing Office).
Abou-Elwafa S.F., Büttner B., Kopisch-Obuch F.J., Jung C., Müller A.E. (2012) Genetic identification of a novel bolting locus in Beta vulgaris which promotes annuality independently of the bolting gene B. Mol. Breed. 29: 989998.

Amasino R. (2010) Seasonal and developmental timing of flowering. Plant J. 61: 1001-1013.

Bastow R., Mylne J.S., Lister C., Lippman Z., Martienssen R.A., Dean C. (2004) Vernalization requires epigenetic silencing of FLC by histone methylation. Nature 427: 164167.

Biancardi E. (2005) Genetics and breeding of sugar beet. Science Publ.

Birve A., Sengupta A.K., Beuchle D., Larsson J., Kennison J.A., Rasmuson-Lestander L., Müller J. (2001) Su (z) 12, a novel Drosophila Polycomb group gene that is conserved in vertebrates and plants. Development 128: 33713379 .

Büttner B., Abou-Elwafa S.F., Zhang W., Jung C., Müller A.E. (2010) A survey of EMS-induced biennial Beta vulgaris mutants reveals a novel bolting locus which is unlinked to the bolting gene B. Theoret. Appl. Genet. 121: 1117-1131.

Dally N., Xiao K., Holtgräwe D., Jung C. (2014) The B2 flowering time locus of beet encodes a zinc finger transcription factor. Proc. Nat. Acad. Sci. 111: 10365-10370.

Dohm J.C., Minoche A.E., Holtgräwe D., Capella-Gutiérrez S., Zakrzewski F., Tafer H., Rupp O., Sörensen T.R., Stracke R., Reinhardt R. (2014) The genome of the recently domesticated crop plant sugar beet (Beta vulgaris). Nature 505: 546-549.

Frerichmann S.L., Kirchhoff M., Müller A.E., Scheidig A.J., Jung C., Kopisch-Obuch F.J. (2013) EcoTILLING in Beta vulgaris reveals polymorphisms in the FLC-like gene BVFL1 that are associated with annuality and winter hardiness. BMC Plant Biol. 13: 52.

Gendall A.R., Levy Y.Y., Wilson A., Dean C. (2001) The VERNALIZATION 2 gene mediates the epigenetic regulation of vernalization in Arabidopsis. Cell 107: 525-535.

Greb T., Mylne J.S., Crevillen P., Geraldo N., An H., Gendall A.R., Dean C. (2007) The PHD finger protein VRN5 func- 
tions in the epigenetic silencing of Arabidopsis FLC. Curr. Biol. 17: 73-78.

He Y., Michaels S.D., Amasino R.M. (2003) Regulation of flowering time by histone acetylation in Arabidopsis. Science 302: 1751-1754.

Helliwell C.A., Wood C.C., Robertson M., Peacock W.J., Dennis E.S. (2006) The Arabidopsis FLC protein interacts directly in vivo with SOC1 and FT chromatin and is part of a high molecular weight protein complex. Plant J. 46: 183-192.

Hemming M.N., Peacock W.J., Dennis E.S., Trevaskis B. (2008) Low-temperature and daylength cues are integrated to regulate FLOWERING LOCUS T in barley. Plant Physiol. 147: 355-366.

Hoffmann C.M., Kluge-Severin S. (2011) Growth analysis of autumn and spring sown sugar beet. Eur. J. Agron. 34: 1-9.

Hohmann U., Jacobs G., Jung C. (2005) An EMS mutagenesis protocol for sugar beet and isolation of non bolting $\mathrm{mu}$ tants. Plant Breed. 124: 317-321.

Jaggard K., Qi A., Ober E. (2009) Capture and use of solar radiation, water, and nitrogen by sugar beet (Beta vulgaris L.). J. Exp. Bot. 60: 1919-1925.

Jaggard K., Werker A. (1999) An evaluation of the potential benefits and costs of autumn-sown sugarbeet in $\mathrm{NW} \mathrm{Eu}$ rope. J. Agric. Sci. 132: 91-102.

Johanson U., West J., Lister C., Michaels S., Amasino R., Dean C. (2000) Molecular analysis of FRIGIDA, a major determinant of natural variation in Arabidopsis flowering time. Science 290: 344-347.

Jung C., Qian W., Büttner B., Hohmann U., Mutasa-Gottgens E., Chia T., Müller A. (2007) Using genomic information for altering bolting and flowering behaviour of crop plants. Mol. Plant Breed. 5: 156-158.

Kim D.-H., Sung S. (2010) The Plant Homeo Domain finger protein, VIN3-LIKE 2, is necessary for photoperiod-mediated epigenetic regulation of the floral repressor, MAF5. Proc. Nat. Acad. Sci. 107: 17029-17034.

Kim D.-H., Sung S. (2013) Coordination of the vernalization response through a VIN3 and FLC gene family regulatory network in Arabidopsis. Plant Cell Online 25: 454-469.

Kim D.-H., Sung S. (2014) Genetic and epigenetic mechanisms underlying vernalization. The Arabidopsis book 12: e0171.

Kim S.Y., He Y., Jacob Y., Noh Y.-S., Michaels S., Amasino R. (2005) Establishment of the vernalization-responsive, winter-annual habit in Arabidopsis requires a putative histone H3 methyl transferase. The Plant Cell Online 17: 33013310.

Köhler C., Grossniklaus U. (2002) Epigenetic inheritance of expression states in plant development: the role of Polycomb group proteins. Curr. Opin. Cell Biol. 14: 773-779.

Le Corre V., Roux F., Reboud X. (2002) DNA polymorphism at the FRIGIDA gene in Arabidopsis thaliana: extensive nonsynonymous variation is consistent with local selection for flowering time. Mol. Biol. Evol. 19: 1261-1271.

Levy Y.Y., Mesnage S., Mylne J.S., Gendall A.R., Dean C. (2002) Multiple roles of Arabidopsis VRN1 in vernalization and flowering time control. Science 297: 243-246.
Lexander K. (1980) Present knowledge of sugar-beet bolting mechanisms. Paper presented at: Proceedings 43rd Winter Congress of the Institut International de Recherches Betteravieres, Brussels.

Li H., Fischle W., Wang W., Duncan E.M., Liang L., MurakamiIshibe S., Allis C.D., Patel D.J. (2007) Structural basis for lower lysine methylation state-specific readout by $M B T$ repeats of L3MBTL1 and an engineered PHD finger. Mol. Cell 28: 677-691.

Luo M., Bilodeau P., Koltunow A., Dennis E.S., Peacock W.J., Chaudhury A.M. (1999) Genes controlling fertilizationindependent seed development in Arabidopsis thaliana. Proc. Nat. Acad. Sci. 96: 296-301.

Michaels S.D., Amasino R.M. (2001) Loss of FLOWERING LOCUSC activity eliminates the late-flowering phenotype of FRIGIDA and autonomous pathway mutations but not responsiveness to vernalization. The Plant Cell Online 13: 935-941.

Musselman C.A., Kutateladze T.G. (2011) Handpicking epigenetic marks with PHD fingers. Nucl. Acids Res. 39(21): 9061-9071.

Pin P.A., Benlloch R., Bonnet D., Wremerth-Weich E., Kraft T., Gielen J.J., Nilsson O. (2010) An antagonistic pair of FT homologs mediates the control of flowering time in sugar beet. Science 330: 1397-1400.

Pin P.A., Zhang W., Vogt S.H., Dally N., Büttner B., SchulzeBuxloh G., Jelly N.S., Chia T.Y., Mutasa-Göttgens E.S., Dohm J.C. (2012) The role of a pseudo-response regulator gene in life cycle adaptation and domestication of beet. Curr. Biol. 22: 1095-1101.

Searle I., He Y., Turck F., Vincent C., Fornara F., Kröber S., Amasino R.A., Coupland G. (2006) The transcription factor FLC confers a flowering response to vernalization by repressing meristem competence and systemic signaling in Arabidopsis. Genes Develop. 20: 898-912.

Shojaei E., Mirzaie-asl A., Mahmoudi S.B., Nazeri S. (2017) Identification of flowering genes in sugar beet based on Arabidopsis homologous genes. J. Agr. Sci. Tech. 19(3): 719-729.

Strange A., Li P., Lister C., Anderson J., Warthmann N., Shindo C., Irwin J., Nordborg M., Dean C. (2011) Major-effect alleles at relatively few loci underlie distinct vernalization and flowering variation in Arabidopsis accessions. PLoS One 6: e19949-e19949.

Sung S., Amasino R.M. (2004) Vernalization in Arabidopsis thaliana is mediated by the PHD finger protein VIN3. Nature 427: 159-164.

Sung S., He Y., Eshoo T.W., Tamada Y., Johnson L., Nakahigashi K., Goto K., Jacobsen S.E., Amasino R.M. (2006) Epigenetic maintenance of the vernalized state in Arabidopsis thaliana requires LIKE HETEROCHROMATIN PROTEIN 1. Nature Genet. 38: 706-710.

Trevaskis B., Hemming M.N., Peacock W.J., Dennis E.S. (2006) HVVRN2 responds to daylength, whereas HVVRN1 is regulated by vernalization and developmental status. Plant Physiol. 140: 1397-1405. 
Yan L., Loukoianov A., Tranquilli G., Helguera M., Fahima T., Dubcovsky J. (2003) Positional cloning of the wheat vernalization gene VRN1. Proc. Nat. Acad. Sci. 100: 62636268.

Yoshida N., Yanai Y., Chen L., Kato Y., Hiratsuka J., Miwa T., Sung Z.R., Takahashi S. (2001) EMBRYONIC FLOWER2, a novel polycomb group protein homolog, mediates shoot development and flowering in Arabidopsis. Plant Cell 13: 2471-2481.
Zhao Z., Yu Y., Meyer D., Wu C., Shen W.-H. (2005) Prevention of early flowering by expression of FLOWERING LOCUS C requires methylation of histone H3 K36. Nature Cell Biol. 7: 1256-1260. 